\title{
LAPAROSCOPIC CHOLECYSTECTOMY AND OVARIECTOMY ... AN EXPERIMENTAL STUDY IN GOATS
}

Kassem MM, Abdel-Wahed RE, El-Kammar MM and Nouh SR

(Dept. of Surgery, Fac. Vet. Med., Alex. University)

\begin{abstract}
To assess feasibility of laparoscopy for cholecystectomy and ovariectomy in goats, (12) apparently healthy adult non pregnant female baladi goats were used. Following aseptic preparation of equipments, instruments and animals, laparoscope was placed on the umbilicus and $360^{\circ}$ scan was performed for orientation and exploration of the abdominal cavity. Ventral abdominal approach offered good visualization of liver, biliary system and reproductive system. Laparoscopic cholecystectomy and ovariectomy ensured minimal invasion and less tissue destruction, visual assessment of hemostasis and smaller body wall incision.
\end{abstract}

\section{INTRODUCTION}

Animal laparoscopy has developed firstly as a diagnostic tool and recently, has progressed to become a mean for surgical procedures and had gained the favor of human and veterinary surgeon (Klohnen, 2002). Laparoscopy had many applications in horses (Bleyaert et al., 1997 and Waguespack et al., 2001), in pony (Boure et al., 2002) and in mares (Ragle et al., 1997). Laparoscopic cholecystectomy had largely replaced the traditional open technique. It offered patients tiny incisions, less postoperative pain, rapid recovery and early return to normal activity (Soper et al., 1990, Wilson and Macintyre, 1993 and Nobuo et al., 2003). 
It had been a useful tool to investigate the role of ovarian function in control of reproductive cycle and to diagnose pregnancy in sheep and goats (Seeger and Klatt, 1980). The most indications for ovarian surgery in ruminants were generally limited to ovariectomy for removal of ovarian tumors (Khar et al., 1996). The most common laparoscopic complications were related to pneumoperitoneum, hemorrhage, and organ perforation. Infection, intestinal burns from electrocautry and cardiac arrest also occurred (Bailey, 1995). The present study aimed to assess the feasibility of laparoscopy for cholecystectomy and ovariectomy in goats.

\section{MATERIALS AND METHODS}

This study was conducted on (12) apparently healthy adult non pregnant female Baladi goats weighting 25-30 kg and aging 1.5-3 years old at Alexandria Endoscopy Association (ALEXEA). Animals were divided into two groups (6 animals of each), for cholecystectomy and ovariectomy. Animals were prepared routinely for laparoscopic examination. Laparoscopic equipments and instruments of Storz, Tuttlingen/Germany were used for these two procedures (Fig., 1). Laparoscopic procedures were performed in dorsal recumbent position (via ventral midline approach) under the effect of inhalation general anesthesia (Fig., 2, A). Basic laparoscopic surgical technique began with establishment of pneumoperitoneum and primary port placement (Fig., 2, C-H). A $360^{\circ}$ scan was performed. The animal was tilted from head down to head up or to neutral to shift abdominal viscera and expose the surgical site. Secondary ports placement was carried out in locations that provide optimal access to liver and ovaries (Fig., 3). 

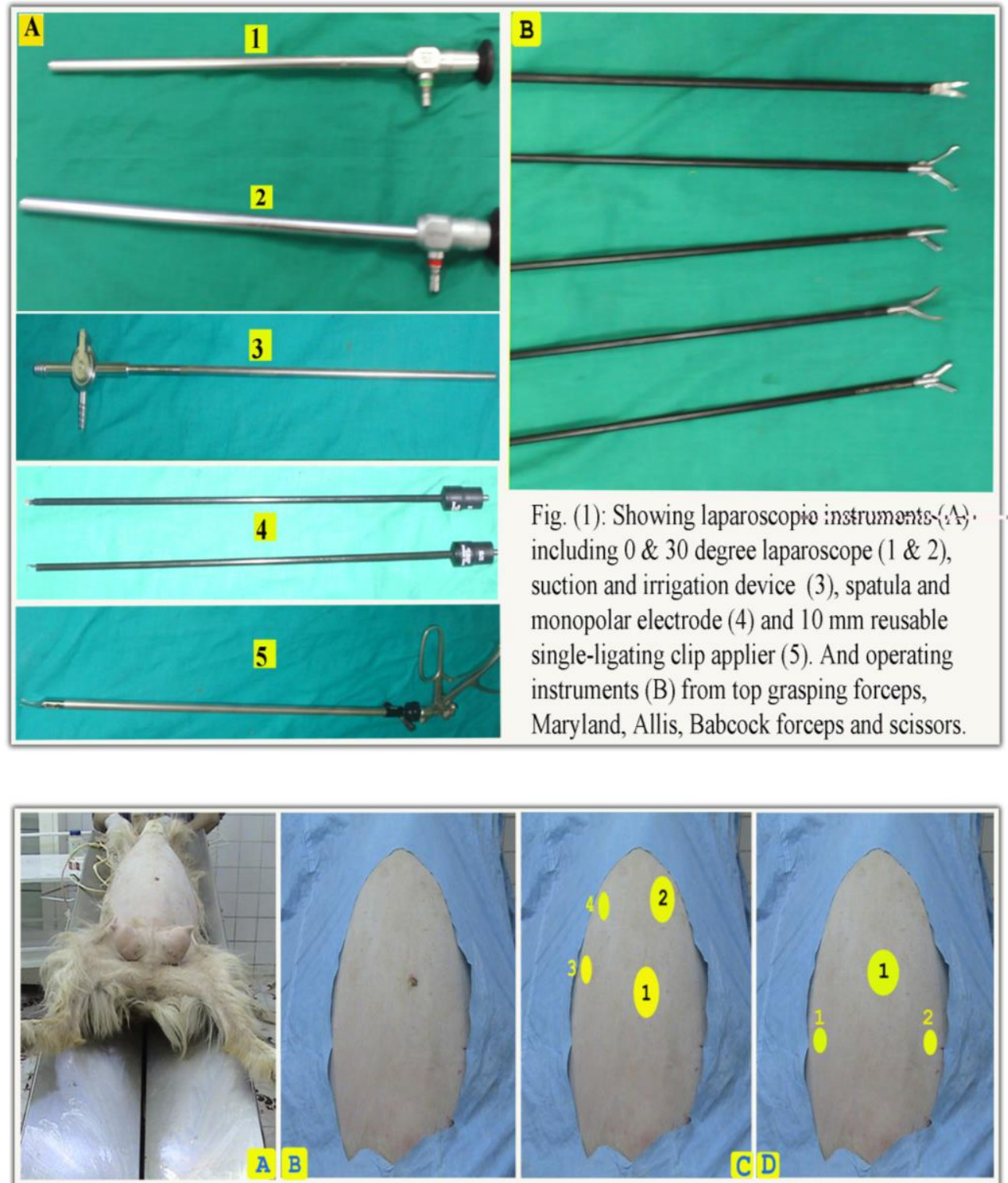

Fig. (2): Showing animal and ports position during laparoscopic procedures: (A) reverse Trendelenburg position (head up), (B) prepared abdomen for ports placements, (C \& D) illustrations for sites of trocar placement according to each operation; (1) $10 \mathrm{~mm}$ optical port, placed at the umbilicus for all laparoscopic procedures. For laparoscopic cholecystectomy (C), another three ports are inserted; two $5 \mathrm{~mm}$ ports for grasping and retracting instruments right to the midline in the sagittal plane of the axilla (3\& \& $)$ and $10 \mathrm{~mm}$ nort for dissecting and ligating instruments left to the midline and caudal to the costal arch (2). For laparposcopic ovariectomy (D), two additional $5 \mathrm{~mm}$ instrumental ports inserted $5 \mathrm{~cm}$ caudal to the optical port and $3 \mathrm{~cm}$ to the right and left of the midline out of superficial epigastric vein (1 \& 2).

$\overline{\text { Kafrelsheikh Vet. Med. J. Vol. } 6 \text { No. } 1 \text { (2008) }}$ 


\section{1-Laparoscopic cholecystectomy:}

Cholecystectomy was conducted on animal in dorsal recumbency with head up and left tilted position. Four ports were used (Fig., 3, 3) according to Kolata and Freeman (1999 a).

Apex and base of gallbladder were grasped with two grasper forceps inserted through the right lateral ports. Apex of the gallbladder was lifted upward and reflected over superior of the right lobe of liver (Fig., 4). The base of the gallbladder was held in tension. The cystic duct was identified at the cystic pedicle.

Monopolar curved dissecting forceps was passed through the left port and began dissection between cystic duct and artery (to create a window for clip applier) $1 \mathrm{~cm}$ distal to neck of the gall bladder toward the common bile duct (Fig., 4, 3-4). Separation of cystic duct anteriorly from cystic artery was performed by gentle opening the jaw of dissector between the duct and artery. The dissector was removed and clip applier was inserted through the left port.

The cystic duct and artery were clipped (three clips; two clips proximally and one distally) as close as possible to the gallbladder. Clip applier was then withdrawn and the scissors was inserted to divide them (Fig., 4, 6-7). The gallbladder was held by placing grasping forceps laterally at the level of the cystic duct and pulling upward. That created a plane of tension between the hepatic gallbladder bed and the gallbladder.

Dissection was performed by using a monopolar hook electrode (after emptying the bladder) and progressed toward the apex of the gallbladder. After dissection of the gallbladder from its bed was completed, the last small attachment of the fundus to the rim of the liver was not cut, but had used to hold the liver still upward to expose the whole gallbladder bed for hemostasis. 
Irrigation and suction device was inserted to clear the operative site and expose bleeding site to facilitate hemostasis. The gallbladder was removed from the abdominal cavity through the $10 \mathrm{~mm}$ port (Fig., 4, 10).

Before closing the abdominal wall, the gallbladder bed was irrigated with saline to remove clots from the operative field and to search for bile leakage or bleeding. The subdiphragmatic region was also irrigated to prevent a subphrenic abscess. After ensuring absence of parietal bleeding, the trocars were removed under direct vision and trocar incisions were closed routinely.

\section{2- Laparoscopic ovariectomy:}

Laparoscopic ovariectomy was conducted on animals positioned in dorsal recumbency in Trendelenburg position (head down) and pelvic limbs toward the T.V monitor. The animal was secured to the table to allow tilting from side to side to enhance ovarian exposure. Three ports were used (Fig., 3, 4).

Large and small intestine were gently manipulated to locate the reproductive tract and then traction was applied to the ovaries to allow manipulation of ovarian pedicles (Fig., 5).

Atraumatic forceps passed through the ipsilateral port was used to grasp an ovary at the cranial pole. The ovary was manipulated with a Babcock forceps to ensure that adequate distance was maintained between the mesovarium and the viscera.

A $5 \mathrm{~mm}$ bipolar electrosurgical forceps was inserted through the contralateral instrument port and placed across cranial aspect of the mesovarium. Electrical current $(11.5 \mathrm{~W})$ was applied until the grasped tissue bubbled and turned white, indicating adequate coagulation. 
The tissues were then transected with laparoscopic scissors (Fig., 5, $3-4)$. Once coagulation and transection of the entire mesovarium was complete (Fig., 5, 5-6), the ovary was removed from the abdomen through the instrumental portal, after removal of the trocar sheath.

Tip of the uterine horn and mesovarium were elevated and observed for hemorrhage. The second ovary was coagulated, transected and removed in a similar manner.

At the end of laparoscopic procedures, entire abdominal cavity was scanned from the pelvic region to the diaphragm to detect any injury or bleeding. Secondary instruments and secondary cannulae were withdrawn under observation of laparoscope.

The laparoscope was removed from the cannula, the valve of the primary cannula was opened to deflate the abdomen and the cannula was removed. Abdominal incisions were closed as usual. Following laparoscopic procedure, the laparoscope, the accessory instruments and all the cannulae were washed and rinsed in tap water and disinfected by soaking in fresh glutraldehyed solution (Cidex- Johnson Johnson U.K) for 15 minutes. Later on they were rinsed with distilled water and dried with clean gauze sponges and then protected by storing in a padded case.

\section{RESULTS}

\section{1- Laparoscopic cholecystectomy:}

Laparoscopic cholecystectomy caused less destruction of tissue. Best exposure of the triangle bounded by the cystic artery, the cystic duct and the hepatic duct was obtained by grasping the fundus of the gallbladder by atraumatic forceps and pushing the organ to the right and upward. 
Using the two-handed dissecting technique, in which the surgeon grasped the tissue exerting correct tension with an atraumatic forceps held in left hand whilst dissecting with the right hand, was preferable and safe than relying on the assistant to grasp and stretch the tissues while the surgeon dissect with the right hand.

Dissection started close to the gallbladder at the junction of the infundibulum with the cystic duct. Division of the superior peritoneal leaf of cystic pedicle, creating a window between cystic artery and duct and lifting the pedicle to review the anatomy from below and behind allowed better access to the vascular and biliary elements.

Using monopolar cautery at a very low voltage (26 watts) was effective and safe. Cystic duct was dissected first after it was freed over a $5-10 \mathrm{~mm}$ area starting from the infundibulum and running toward the common bile duct. Laparoscopic clips were effective in providing hemostasis and were easily applied to the cystic duct and artery during laparoscopic cholecystectomy.

Dealing with cystic duct first (clipping and division) provided better access to the cystic artery. Safe dissection of cystic duct was performed without intraoperative cholangiography. Constant downward traction over the infundibulum of the gallbladder allowed exposure of the operative field. The low voltage cautery allowed well dissection of gallbladder bed. Emptying the gallbladder allowed the organ to be easily grasped, improved exposure of cystic pedicle and prevented accidental leakage of bile.

Extraction of the gallbladder through the umbilical port with its cannula was always possible. No cases required conversion to open operation. Intraoperative complications as bleeding from liver bed was encountered in two patients and controlled by electrocautery. Gallbladder perforation occurred in one case and overcome by irrigation and suction. 


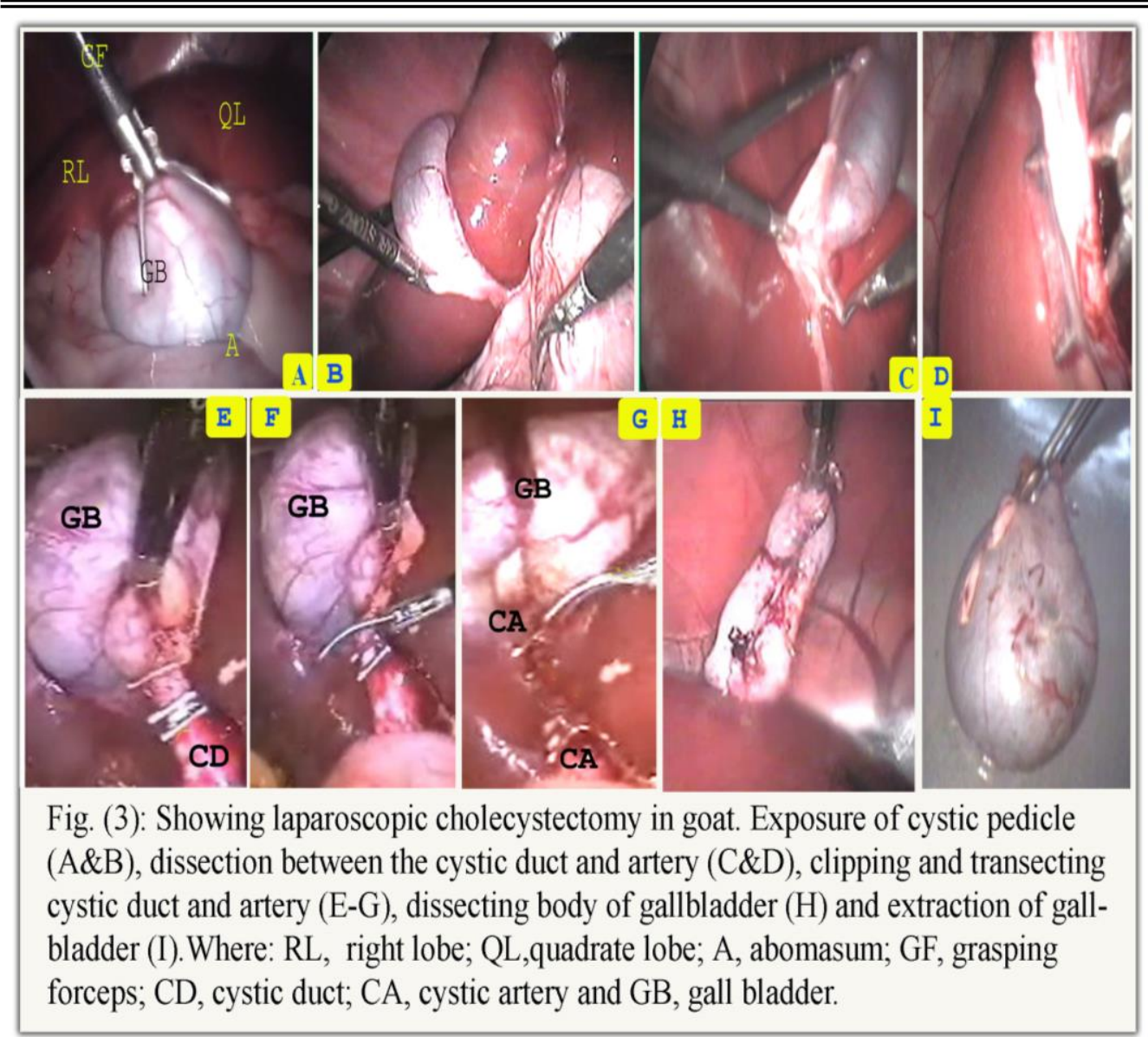

\section{2- Laparoscopic ovariectomy}

Laparoscopic ovariectomy provided good visualization of ovary and mesovarium and visual assessment of hemostasis. The procedure was not considered technically difficult and no major operative complications were experienced.

The proper positioning of ovary (outstretched proper ovarian ligament) with grasping forceps was important to efficient application of electrosurgical forceps across the mesovarium. The sequential coagulation and transection was considered the rate-limiting step of the 
surgical procedure. About $3 \mathrm{~mm}$ of tissues was coagulated at one time; on average, 3-5 coagulation and transection cycles were required per ovarian pedicle. Intraoperative hemorrhage occurred in two cases.

Transection of the right ovarian artery in one goat without appropriate coagulation resulted in excessive hemorrhage that was quickly controlled by grasping the cut end of the artery with the electrosurgical forceps and its cauterization. The severed ovarian tissues were then removed as with cholecystectomy.

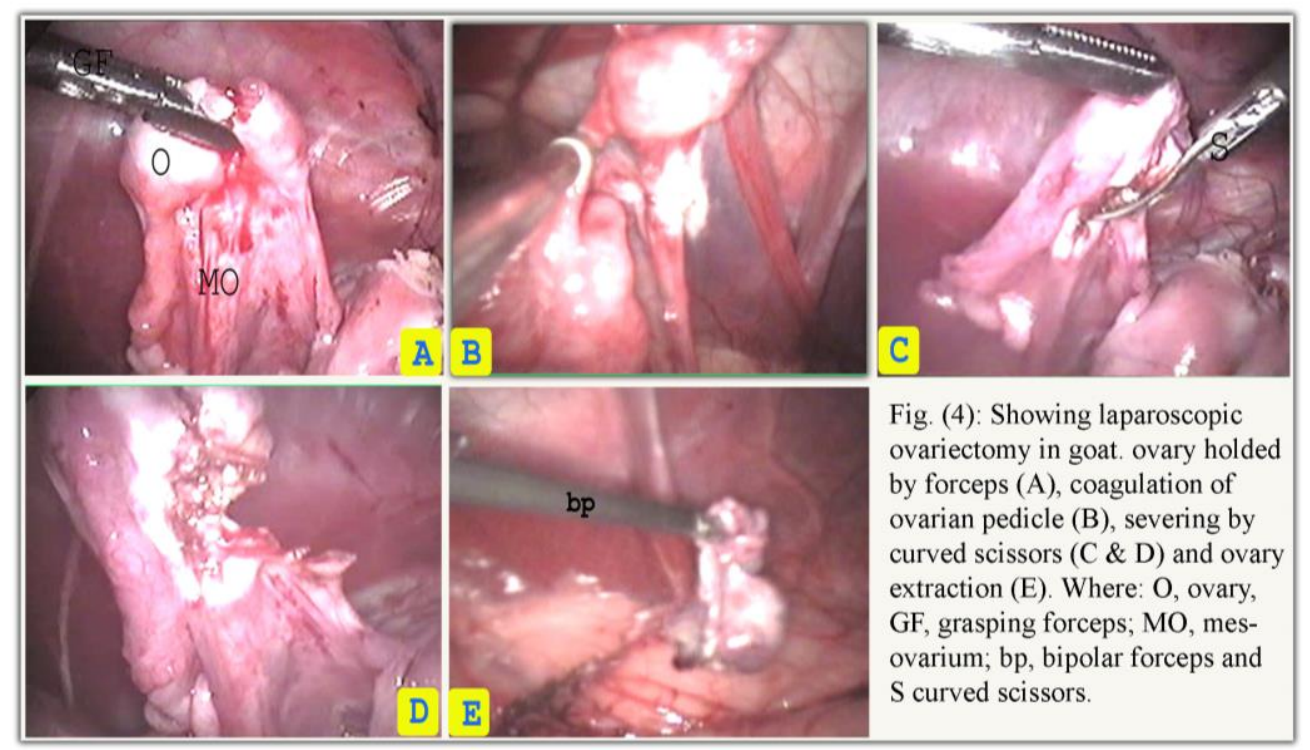

Complications inherent to all laparoscopic procedures during the course of this study (Fig., 6) included insufflation of the omental bursa (2 cases) in which the abdominal cavity appeared as white, fat-lined and relatively featureless cavity and subcutaneous emphysema (one case). Two cases of liver bed bleeding, one case of gallbladder perforation and one case of mesovarium bleeding were recorded as intraoperative complications in goat laparoscopy. 

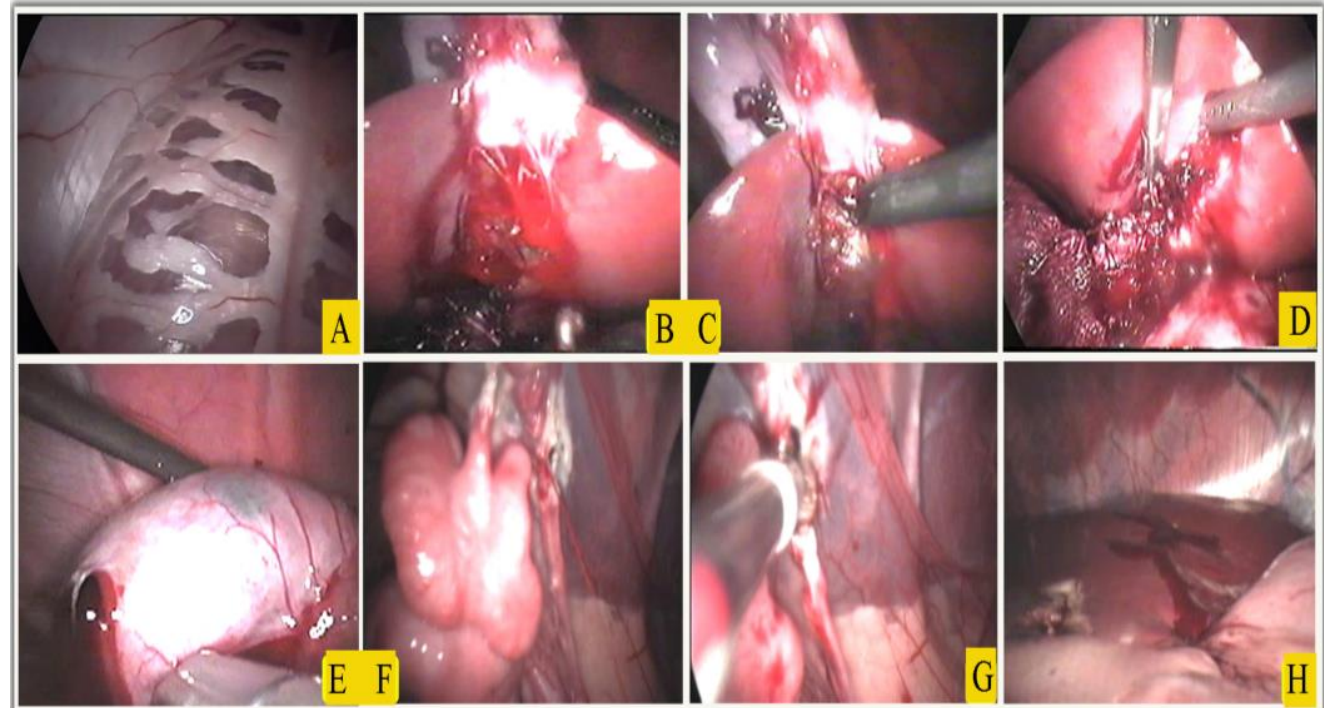

Fig. (5): Showing common laparoscopic complications. Insufflated omental bursa (A), bleeding of liver bed and its hemostasis (B \& C), clearing of liver bed using irrigation and suction device (D), perforation of gall bladder $(\mathrm{E})$, bleeding and hemostasis of mesovarium $(\mathrm{F} \& \mathrm{G})$, and liver bleeding following needle biopsy.

\section{DISCUSSION}

Laparoscopic cholecystectomy considered as an attractive alternative to standard cholecystectomy. Soper et al. (1990) and Johnston and Kaplan (1993) used laparoscopic cholecystectomy rather traditional open technique for treating patients with chronic cholecystitis and considered this technique as a new gold standard for treating such patients.

Laparoscopic cholecystectomy provided good visualization of gallbladder and common bile duct causing less destruction of tissues and thereby, reduces pain and shortens postoperative ileus. Schippers (1993) obtained faster return of intestinal motility following laparoscopic cholecystectomy than did open cholecystectomy in dogs. Calhoun et al. (1994) and Lujan et al. (1998) approved laparoscopic cholecystectomy as a safe and effective treatment for acute and chronic cholecystitis. In this study, no cases required conversion to open operation. 
Intraoperative complications during laparoscopic cholecystectomy as bleeding of liver bed and gallbladder perforation are less than those described in literature following chronic cholecystitis or open cholecystectomy (Caputo et al., 1992, Miller and Kimmelsteil, 1993 and Duca et al., 2003). This variation may be attributed to nature of this study (experimental). Using of $30^{\circ}$ viewing scope, early decompression of the gallbladder and careful dissection were a key factor for the success of the techniques. This maneuver comes in consistent with advises of Hunter (1993) and Calhoun et al. (1994). Perissat et al. (1990) and Dubois et al.(1990)utilized intraoperative cholangiography to compensate limitations of laparoscopic cholecystectomy.

Cholangiography not only allows diagnosis and management of common bile duct stones, but also provides a road map of ductal anatomy. Extraction of the gallbladder through umbilical port with its cannula was always possible among this study. Kolata and Freeman $(1999 \mathrm{~b})$ used a specimen retrieval bag for removal of gallbladder to prevent leakage of bile.

Laparoscopic ovariectomy in goats, via ventral abdominal approach, provided good visualization of ovary and mesovarium, allowed tensionless manipulation of the mesovarium during pedicle transection, visual assessment of hemostasis and smaller body wall incision. Similar advantages were recorded in mares (Ragle and Schneider, 1995 and Rodgerson et al., 2001) and in cattle (Bleul et al., 2005). Hofmeyr (1987) recorded peritonitis and life-threatening hemorrhage of the ovarian pedicle following ovariectomy via colpotomy.

During laparoscopy, ovariectomy is performed under visual control reducing the risk of complications. Bleul et al. (2005) found that incisions resulting from laparoscopy are unlikely to interfere with well being of the animal and facilitate their immediate reintroduction into the $\overline{\text { Kafrelsheikh Vet. Med. J. Vol. } 6 \text { No. } 1 \text { (2008) }}$ 
herd after the operation. Using of only two instrumental ports was satisfactory. Shoemaker et al. (2004) founded that limiting the number of ports decreased the time required to suture the abdominal wound. Meanwhile, Ragle and Schneider (1995) described a technique for multiple working ports as more appropriate for removal of unilateral diseased ovary.

Application of electrosurgical coagulation and transection of ovarian pedicle was chosen in this study as a reliable means of mesovarian hemostasis. Other numerous methods for hemostasis of mesovarium and associated ovarian vessels are available as ligature application (Boure et al., 1997), laser techniques (Palmer, 1993), harmonic scalpel (Dusterdieck et al., 2002), stapling instruments (Doran et al., 1998) and vascular clips (Rodgerson et al., 2001). Ligature slippage has also been associated with inadequate hemostasis (Rodgerson and Hanson, 2000).

Ventral abdominal approach proved useful for cholecystectomy and ovariectomy offering good visualization of liver, gallbladder, reticulum, abomasum, intestine, spleen, reproductive system and urinary bladder. Monnet and Twedt (2003) showed that this approach is not suitable for dogs, as the flaciform ligament may hinder visualization of anterior abdomen. Habel (1975) mentioned that flaciform and round ligaments disappeared in adult ruminants.

\section{REFERENCES}

- Bailey, R. W. (1995): General considerations. In: Bailey, R. W. and Flowers, J. F. eds. Complications of laparoscopic surgery. St. Louis Quality Medical Publishing. 
- Bleul, U., Hollenstein, K. and Ka“hn, W. (2005): Laparoscopic ovariectomy in standing cows. Animal Reproduction Science, 90 (34): $193-200$.

- Bleyaert, H.F.; Brown, M. P.; Bonenclark, G. and Bailey, J.E. (1997): Laparoscopic adhesiolysis in a horse. Veterinary surgery 26:492-496.

- Bouré, L. P., Marcoux, M. and Laverty, S. (1997): Paralumbar fossa laparoscopic ovariectomy in horses with use of Endoloop ligatures. Vet. Surg. 26:478-483.

- Bouré, L. P.; Pearce, S. G.; Kerr, C. L.; Lansdowne, J. L.; Martin, C. A.; Hathaway,A. L. and Caswell, J. L. (2002): Evaluation of laparoscopic adhesiolysis for the treatment of experimentally induced adhesions in pony foals. American Journal of veterinary research 63:289-294.

- Calhoun, P. C.; Adams, L. H. and Adams, M. R. (1994): Comparison of laparoscopic and minilap cholecystectomy for acute cholecystitis. Surg. Endosc., 8: 1301-1304.

- Caputo, L.; Aitken, D. R.; Mackett, M. C. and Robles, A. E. (1992): Iatrogenic bile duct injuries. The real incidence and contributing factors-implications for laparoscopic cholecystectomy. Am. Surg., 12: 766-771.

- Doran, R.; Allen, D. and Gordon, B. (1998): Use of stapling instruments to aid in the removal of ovarian tumours in mares. Equine Vet. J., 20:37-40.

- Dubois, F.; Icard, P.; Berthelot, G. and Levard, H. (1990): Coeliscopic cholecystectomy. Ann. Surg., 211: 60-63.

- Duca, S.; Bala, O.; Al-Hajjar, N.; Iancu, C.; Puia, I. C.; Munteanu, D. and Graur,F . (2003): Laparoscopic cholecystectomy incidents and complication. A retrospective analysis of 9542 consecutive laparoscopic operations. HPB (Oxford), 5(3): 152-158. 
- Dusterdieck, K. F.; Pleasant, R. S.; Lanz, O. I. Saunders, G. K. and Howard, R. D. (2002): Evaluation of the harmonic scalpel for standing laparoscopic ovariectomy in horses. In: Scientific presentation abstracts, 12th Annual ACVS Symposium, 2002, San Diego, California.

- Habel, R. E. (1975): Ruminant digestive system. In: Getty, R., editor. The anatomy of the domestic animals. W. B. Saunders Company; p. 908-913.

- Hofmeyer, C.F. B. (1987): The female genitalia. In: Hofmeyer, C. F. B., Editor, Ruminant urogenital surgery. Iowa State University Press, p.122-147.

- Hunter, J. G. (1993): "Exposure, Dissection, and Laser versus Electrosurgery in Laparoscopic Surgery.” Am. J. Surg., 165:492-496.

- Johnston, D. E. and Kaplan, M. M. (1993): Pathogenesis and treatment of gallstones. N. Engl. J. Med. 328:412-421.

- Khar, S. K.; Mannarl, M. N. and Singh,Jit (1996): The genital system Section- B female. In: ruminant surgery by Tyagi, R. P. S. and Singh, Jit eds. (1996) 3rd ed. CBS Shahdara, Delhi-110032(India).

- Klohnen, A. (2002): History of laparoscopy in animals and humans. In: Fischer, A. T., editor. Equine diagnostic and surgical laparoscopy. Philadelphia: WB Saunders; p. 3-5.

- Kolata, R. J. and Freeman, L. J. (1999 a): Access, port placement and basic endosurgical skills. In: Freeman, L. G., editor. Veterinary endosurgery. St. Louis: Mosby; p.44-60.

- Kolata, R. J. and Freeman, L. J. (1999 b): Minimally invasive surgery of the liver and biliary system. In: Freeman, L. G., editor. Veterinary endosurgery. St. Louis: Mosby; p.151-159. 
- Lujan, J. A.; Parrilla, P.; Robles, R.; Marin, P. Torralba, J. A. and Garcia-Ayllon, J. (1998): Laparoscopic cholecystectomy Vs open cholecystectomy in the treatment of acute cholecystitis. Arch. Surg., 133(2): 173-175.

- Miller, R. E. and Kimmelsteil, F. M. (1993): Laparoscopic cholecystectomy for acute cholecystitis. Surg. Endosc., 7: 296-299.

- Monnet, E. and Twedt, D. C. (2003): Laparoscopy. Vet. Clin. Small Anim., 33: 1147-1163.

- Nobuo, M.; Junji,I; Kazuyuki, S. and Shigeru,S.(2003): Indication and limitation of laparoscopic cholecystectomy. Gastroenterological Surgery, 26(11):1589-1592.

- Palmer, S. E. (1993): Standing laparoscopic laser technique for ovariectomy in five mares. J. Am. Vet. Med. Assoc. 203:279.

- Perissat, J.; Collet, D. and Belliard,R. (1990): Gallstones: laparoscopic treatment-cholecystectomy and lithotripsy. Our own technique. Surg. Endosc. 4: 15-17.

- Ragle, C. A. and Schneider, R. K. (1995): Ventral abdominal approach for laparoscopic ovariectomy in horses. Vet. Surg., 24:492-497.

- Ragle, C. A.; Southwood, L.L. Galuppo, L. D. and Howlett, M. R. (1997): Laparoscopic diagnosis of ischemic necrosis of the descending colon after rectal prolapse and rupture of the mesocolon in two postpartum mares. Journal of the American Veterinary Medical Association 210:1646-1648.

- Rodgerson, D. H. and Hanson, R. R. (2000): Ligature slippage during standing laparoscopic ovariectomy in a mare. Can. Vet. J., 41:395-397. 
- Rodgerson, D. H., Belknap, J. K. and Wilson, D. A. (2001): Laparoscopic ovariectomy using sequential electrocoagulation and sharp transection of the equine mesovarium. Vet. Surg., 30: 572-579.

- Schippers, E. (1993): Laparoscopic cholecystectomy: a minor abdominal trauma? World J. Surg., 17: 539-542.

- Seeger, K. H. and Klatt, P. R. (1980): Laparoscopy in the sheep and goat. In: animal laparoscopy by Harrison, R. M. and Wildt, D. E. eds. Chapter 6 Willimas \& Wilkins Baltimore, London.

- Shoemaker, R. W.; Read, E. K.; Duke, T. and Wilson, D. G. (2004): In situ coagulation and transection of the ovarian pedicle: An alternative to laparoscopic ovariectomy in juvenile horses. Can. J. Vet. Res., 68(1): 232.

- Soper, N. J.; Stockmann, P. T.; Dunnean, D. L. and Ashley,S. W. (1990): Laparoscopic cholecystectomy: the new gold standard? Arch. Surg., 125: 1434-1435.

- Waguespack, R., Belknap, J. and Williams, A. (2001): Laparoscopic management of postcastration haemorrhage in a horse. Equine Veterinary Journal 33:510-513.

- Wilson, R. G. and Macintyre, I. M. C. (1993): Impact of laparoscopic cholecystectomy in the UK: a survey of consultants, Br. J. Surg. 80:346. 
استخدام المنظار الجر احى لاستئصال المرارهو المبايض ... در اسه تجريبيه فى الماعز د./ مصطفى قاسم - د.//رضان عبد/لواحد - د./ محمود الكمار - د./ سمير نوح (قسم الجراحة - كلية الطب البيطرى - خامعة الاسكندريه)

استهدفت الدراسة إمكانية استئصال المرارة والمبياض باستخدام المنظار الجراحى فى إناث الماعز. نم إجراء هذه الرسالة على عدد 12 أنثى من الماعز السليمة ظاهريا حيث قسمت الى مجموعتن. بعد الفحص الإكلينيكي للحيوان وتخديره وتحضيره لإجراء المنظار البطنى تم وضع الحيوان مستلقيا على الظهر واستخدمت ابرة فيرس لضخ ثانى أكسيد الكربون داخل الفراغ البريتونى. بعد ذلك تم إدخال المنظار من خلال كانيولا أساسيه فى منطقة السرة كما تم إيلاج ثلاثة كانبولات ثانوية أخرى لإدخال المعدات اللازمة للجراحة كالجفت الماسك وجفت الكى والمقص الجراحى. وقد أوضحت الدراسة أن وضع استلقاء الحيوان على ظهره بدا مناسبا لاستئصال الررارة بالمنظار حيث أتاح الروئة الجيدة للمرارة والجهاز المرارى وإحداث قدر ضئيل من تدمير الأنسجة. كما أظهرت الدراسة أيضا أن استئصال المبياض بالمنظار الجراحى يضمن إتاحة الروئة المتميزة لمعلاق المبيض وتحديد مصدر النزيف والسيطرة علية. ومما تقام يتبين ان المنظار الجراحى للبطن يساعد فى الروية المباشرة للأعضاء الاخلية أثناء إجراء استئصال المرارة والمبياض فى إناث الماعز مما يضمن غياب المضاعفات وسهولة إدراكها والتغلب عليها ان وجدت. 